\title{
INEQUALITY AND CONFLICT AS DRIVERS OF COOPERATION: THE LOCATION OF WINE COOPERATIVES IN PRE-1936 SPAIN
}

\author{
Samuel Garrido \\ Department of Economics. Universitat Jaume I
}

\begin{abstract}
As it is usually believed that cooperatives made a great contribution to the modernisation of agriculture and when they began to spread agriculture still had a great weight in European economies, it is of interest to know why agricultural cooperatives had uneven success, both from one crop to another and between and within countries. In this article I focus on the intriguing case of wine, a product of great importance to Mediterranean Europe. After defending that, in actual fact, wine cooperatives were generally unable to offer members important economic advantages, I argue that they only flourished where some 'local' factor increased the attraction of belonging to them and, in addition, it was possible to finance their construction. I use what happened in France as a reference and show that in Spain both circumstances only converged in (a part of) Catalonia, as a paradoxical result of inequality and the social conflicts caused by a sharecropping contract called rabassa morta.
\end{abstract}

\section{Introduction}

Although agricultural cooperatives began to spread rapidly across Europe as of the late nineteenth century, in the short and medium term their development was very unequal, both between crops and between geographical areas. Because it was often due to the intervention of 'local' factors, we still do not have a precise overall knowledge explaining why the cooperative movement sometimes thrived and at other times it did not. In this article I use data from Spain prior to the civil war of 1936-39 and make many allusions to France to analyse the intriguing case of wine.

Cooperatives emerged in response to new market conditions, but social conflict, religious proselytism and political struggles also played a part. There was a time when historical studies on cooperation paid a great deal of attention to such 'non-economic' factors, which were gradually forgotten - sometimes in favour of 'cultural' factors when research started to be mainly conducted by economic historians and the use of econometric techniques became widespread. ${ }^{1}$ Here, econometric techniques are used

\footnotetext{
${ }^{1}$ Although conflict has continued to occupy an important place in studies on Ireland (Ó Gráda 1977;

O’Rourke 2007a, 2007b; Colvin and Mclaughlin 2014; McLaughlin 2015).
} 
and a great deal of attention is paid to them again.

In a recent essay, Allen and Lueck (2019) maintain that, although the majority of the world's grapes have always come from owner-operated family farms, wine ceased to be produced mostly in the farmer's cellars in the mid-nineteenth century, becarsuse thereafter 'and carrying on for the next 100 years' (p. 335) vineyards and wineries vertically disintegrated and most of the wine was made by firms capable of obtaining economies of scale. They were cooperative wineries in Europe and corporate wineries in North America, 'but the fundamental forces were the same in both cases' (p. 336). What needs an explanation, then, is why the same industrial pattern occurred around the world. Allen and Lueck believe it resulted from the fact that 'technical innovations occurred that reduced the transaction cost environment at the winery stage, but not at the level of the vineyard' (p. 330). Their argument about cooperative wineries is a version of the thesis which postulates that cooperatives have more strength in agriculture than in other economic sectors because they allow the advantages of the family farm (low supervision and monitoring costs) to be combined with the achievement of economies of scale (Valentinov 2007, Federico 2008: 133). ${ }^{2}$ But their claims concerning when they arose and how they evolved are incorrect.

Even though the first cooperative wineries appeared in Germany around $1870,{ }^{3}$ in France, Italy and Spain, the world's three main wine producers, they were practically non-existent prior to 1900 and in the late 1930s their market share was still low - just over 15 per cent in France, around 5 per cent in Spain and less than 5 per cent in Italy. Moreover, most cooperative wineries were concentrated in a single wine-growing region in each country: south-eastern France, northern Italy, and Catalonia. They only began to expand on a more generalised way by1950, reaching their maximum market shares by the year 2000: 52 per cent in France, 55 in Italy and 70 in Spain.

Consequently, what really needs to be explained is, first, why cooperative wineries had little strength before the Second World War; second, the reasons for their puzzling spatial distribution during that period; and third, why they flourished in the second half of the twentieth century.

The first issue has been addressed in a companion paper (XXX 2019), which shows that the pre-World War II cooperative wineries were generally unable to offer

\footnotetext{
${ }^{2}$ Fernández and Simpson (2017) argued that this thesis could not be applied to cooperative wineries.

${ }^{3}$ Berget $(1901,1902)$. The rest of the paragraph is based on XXX (2019).
} 
their members substantial economic advantages over non-members; the matter will be briefly taken up in Section 4 of this article. The reasons for the post-1945 growth have been analysed by Román (2011), Medina-Albadalejo (2016), Planas and MedinaAlbadalejo (2017), Medina-Albadalejo and Planas (2020), and Fernández and Simpson (2017), who convincingly maintain that it was the result of governments wanting to use cooperatives to regulate the wine sector and offering them subsidies and low-interest loans - something that, on a smaller scale, was already being carried out in France in the 1930s. My aim here is to analyse the reasons underlying the unequal distribution throughout Spain of the 125 cooperative wineries built before 1936, because 86 of them were in Catalonia - 61 in the province of Tarragona (Figure 1). Catalonia was home to 18 per cent of the vines in Spain, 6 per cent of them being in Tarragona.

\section{$<<$ Figure $1>>$}

Allen and Lueck (2019) reduce the 'organization of vineyards and wineries' to three 'stylized facts' and consider everything that does not fit into them to be exceptions of no interest. However, I will show that the concentration of the first Spanish cooperative wineries in Catalonia was the result of a 'local' social factor, namely, the conflicts generated by a sharecropping contract called rabassa morta. They acted as a detonator for the appearance of the first Spanish cooperative wineries in Tarragona and led many wealthy wine-growers to use cooperatives to process part of their grapes, unlike what happened in the rest of Spain and France.

After briefly paying attention to the theory of farm cooperatives in Section 2, in Sections 3 and 4 I recall how European agricultural cooperatives emerged and argue that joining a cooperative winery was usually only (moderately) attractive to small wine-growers. In order to have a reference that helps to understand what happened in Spain, in Section 5 I focus on France, while in Sections 6, 7 and 8 I analyse the determinants of the creation of cooperative wineries in Spain, explain what occurred in Catalonia, and perform a detailed examination of the province of Tarragona.

2. Collective decisión-making and monitoring costs were high in Spain

One of the most suggestive contributions to the theory of agricultural cooperatives 
was proposed by Hansmann $(1996,1999)$. When farmers form a cooperative they become the owners of the firm that purchases their harvests or sells them the supplies they need. This offers them a number of advantages (including making it unlikely that the firm they own will cheat them), but it also has its costs. Hansmann assumes that when the costs of market contracting are higher than the costs of ownership the incentives to set up cooperatives will increase.

The main costs of market contracting result from the possible presence of three dysfunctions. First, simple market power, when there are firms capable of raising sales prices or lowering purchase prices by manipulating the level of supply or demand. Second, ex-post market power (or lock-in), which arises when, after entering into a transactional relationship with a firm, it is necessary to make substantial transaction-specific investments - that is, investments which will be difficult to recover completely if the relationship ends. ${ }^{4}$ And third, asymmetric information between the contracting parties. In the case we are dealing with here, this refers to the fact that there are firms that have more information than the farmers about some of the attributes of the crops they buy from them or the supplies they sell to them. In the early twentieth century farmers often complained that the fertilisers they purchased on the market did not meet the promised standards of quality. It was very costly for them to commission product analyses before purchasing on an individual basis, but the larger scale purchases made by the cooperatives did make such analyses cost-effective and many of the early cooperatives sold fertilisers.

On the other side of the scale, two of the costs of ownership are particularly relevant. The first is the cost of collective decision-making, which Hansmann (1996: 136) considers cooperatives can usually keep to a minimum because, as agricultural products tend to be very homogeneous, 'a critical advantage for farm cooperatives' is 'the extreme homogeneity in interest among the typical cooperatives' members'. Second, the costs involved in monitoring the operations and the management of the cooperative, which Hansmann assumes are also often low, among other reasons

\footnotetext{
${ }^{4}$ If the firm then made the initial conditions of the deal tougher, whoever made the investment would have to accept the modification or pay the high price that leaving the relationship entails. According to Henriksen (1999), if the costly investments needed to adopt new butter production technologies were made by farm cooperatives, they were less likely to fall into this type of situation than when investments were made by other types of firms or by individual farmers, which explains the rapid success of cooperative dairies in late nineteenth century Denmark.
} 
because the homogeneity of interests makes it cheap for members to obtain information on the cooperative and to exchange opinions with the other members and the board of directors.

Hansmann concludes that in farm cooperatives the costs of ownership are often lower than the costs of market contracting even when the latter are low. To encourage the creation of cooperatives, in many countries governments granted them tax and credit subsidies and other privileges. But Hansmann, who draws heavily on examples from marketing cooperatives in the United States to illustrate his arguments, believes that the fact the cooperative movement was already well developed in the United States before the state began to grant it privileges suggests that what has played a key role in the consolidation of farm cooperatives is not so much state aid as the favourable relationship between the benefits and the costs of ownership.

Yet there is evidence that in the first Spanish cooperatives the costs of monitoring and collective decision-making were very high, which is closely related to the fact that, although the products that their members grew could have a high degree of homogeneity, in Spain (and other European countries) the members of the cooperatives had to bear the costs caused by the fact that they usually came from very different social backgrounds (Castillo 1979, Garrido 1996), so that their interests often diverged. And everything seems to indicate that much of the responsibility for the fact that farm cooperatives had little force in pre-1936 Spain can be attributed to the lack of state intervention. I develop these ideas further in the next section.

\section{Cooperation among unequals}

The first French cooperative winery was created in 1893 by a group of small winegrowers with a socialist ideology (Clique 1931: 155). Many similar cases are known, but it was far more common for cooperatives to be founded by wealthy farmers (or by activists with their support) who wanted to attract small farmers in order to prevent them from succumbing to the temptation of socialism (Castillo 1979). The cooperatives were also often seen as 'a sure and solid way of maintaining political influence in the countryside' (Rinaudo 1980: 79). And in countries like Spain, Italy or Belgium they spread largely as a result of the efforts of the Catholic Church, which in addition to fearing socialism wanted to avoid the 'dechristianisation' of the rural 
population. ${ }^{5}$

For all these reasons, the cooperative movement often brought together people who were socially heterogeneous, but who shared religious beliefs, political militancy or the fear of a revolution. As social heterogeneity meant that the costs of collective decision-making were high and members with more resources (who normally made up the major part of the boards of directors, either in person or through representatives) did not usually need the economic services of the cooperatives, they had many incentives not to assume the costs that using them entailed and frequently did not use them. In the French republic and the kingdom of Spain, the characteristics of the national political systems determined whether this would hinder the development of cooperatives.

In France, a law enacted in 1884 called agrarian cooperatives syndicats agricoles, which were immediately taken advantage of by wealthy landowners and rural notables - who could either be clerical aristocrats or republican politicians (AugéLaribé 1926, Barral 1968, Cleary 1989, King 1996) - to gain social and electoral influence. Because the countryside was a vital source of votes, nobody objected to the state providing them with low-interest loans (between 1.5 and 3 per cent) and other subsidies (Ministère de l'Agriculture 1911, 1917; Cleary 1989). The intention was for the syndicats agricoles to act as multipurpose cooperatives (distribution of fertilisers, joint purchase of machinery, etc.) and to serve as a platform for the emergence of cooperatives specialising in the industrial transformation and marketing of crops.

As specialised cooperatives usually require more investment than multipurpose cooperatives, they typically demand more discipline from members and it is more difficult to withdraw from them. For example, while cooperatives for the joint purchase of fertilisers and other agricultural necessities rarely force their members to utilise only the articles that they distribute and those who break the rules or want to leave seldom face important penalties, cooperative wineries normally use formal contracts and substantial penalties to oblige members to remain tied to them for long periods and to hand all the grapes they produce (or a pre-established fixed amount of grape) over to them (XXX 2019). That difference made it uncommon for wealthy

\footnotetext{
${ }^{5}$ Fay (1920: 129) explained the growth of cooperation in Belgium in the following terms: 'The Socialist and Catholics have sought to conquer the farmer by the weapons of co-operation ... The socialist agitation alarmed the Church, and it is they who, with the patronage of the landed aristocracy and the Government, have directly created all this growth'.
} 
landowners who were members of syndicats agricoles to enter cooperative wineries and other specialised cooperatives. But government subsidies allowed small and medium-sized farmers in France to set them up on their own if they wanted to do so. This was not the case in Spain.

In theory, Spain tried to imitate the French plan regarding agricultural cooperatives and a law passed in 1906 also called them sindicatos agrícolas. ${ }^{6}$ But the political parties that controlled the apparatus of the state decided not to use them to attract votes and wanted to prevent anyone from doing so. Consistent with this, the state did not provide them with access to credit or almost any other support. They were founded mainly by activists from church circles who had the backing of large Catholic landowners and basically attracted small farmers. The combination of, on the one hand, the lack of state support and, on the other, the great social inequality existing between the landowners who encouraged the Church to found cooperatives and the small farmers who came to them gave rise to an unfavourable framework for the Spanish cooperative movement to become firmly established: most of the 5,665 sindicatos agrícolas founded up to 1927 carried out little or no activity and only 2,151 of them had survived by $1933 .^{7}$ Even when they were very active, they usually operated in an undemocratic way and it was difficult, if not impossible, for the members to monitor the directors. Both Castillo (1979) and Garrido (1996) maintain that this was a major cause of their very short half-lives.

Internationally, marketing cooperatives have had greater success in some products than in others, which makes it reasonable to suppose that the costs of collective action are greater in some products than in others (Hoffmann and Libecap 1991, Hansmann 1996: 139, Federico 2008: 135, Fernández and Simpson 2017: 123). Nevertheless, in pre-1936 Spain marketing cooperatives were not strong for any crop whatsoever (Commission International d'Agriculture 1931). The vast majority of Spanish farm cooperatives were supply cooperatives that sold fertilisers. This is related to the farmers' desire to escape the problem of asymmetric information referred to above, but it was also because such cooperatives could be set up with little investment. Although many scholars believe that grapes were among the crops that

\footnotetext{
${ }^{6}$ The statements in this paragraph are based on Garrido $(1996,2007)$.

${ }^{7}$ In 1933 there were 4,255 sindicatos agrícolas, 2,104 of which were created after 1927 (Dirección General de Agricultura 1934). We do not know how many had been founded altogether between 1927 and 1933 or, therefore, what percentage of them remained in 1933.
} 
offered more difficulties for cooperatives to control free-rider behaviour, ${ }^{8}$ wine cooperatives were the marketing cooperatives that enjoyed the greatest market share ( 5 per cent, as indicated). Yet if the province of Tarragona is excluded the figure drops to 3 per cent, whereas in Tarragona it was 40 per cent.

\section{Cooperative wineries were only attractive to small wine-growers}

Using data from Spanish and French cooperatives and non-parametric tests, elsewhere it has been shown that the null hypothesis that the prices of wine sold by cooperatives and those of wine of any origin were equal cannot be rejected (XXX 2019).

Obviously, production costs are as important as selling prices, but information about them is scarce and of poor quality.

In the literature of the time it was usual to assume that large wine-growers produced enough grapes to make the adoption of the latest technical innovations in their cellars a profitable undertaking, that their production costs were at least similar to those of cooperative cellars and that they would tend to stay away from cooperatives (for example, Riba 1917, Gide 1926: 146). ${ }^{9}$ What was said about the French department of Var illustrates this magnificently:

In the small cellars where the wine is housed in wooden vats, the manual presses and crushers have continued to exist... In contrast, the most important wineries are equipped with mechanically driven high-performance material identical to that of cooperative wineries. [Like the latter,] ... they keep the wine in cement tanks. ${ }^{10}$

Undoubtedly, cooperatives did have lower costs than small wine-growers, but a rigorous analysis of the issue was never carried out. Based on mere speculation,

\footnotetext{
${ }^{8}$ The matter is discussed in XXX (2019) and the conclusion reached is that this is not the case.

${ }^{9}$ What occurred in the wine sector, therefore, was in no way similar to what Henriksen (1999: 61) said about the butter industry in Denmark, where not even the biggest farmers usually had the cows necessary for a steam-driven centrifugal cream separator to work at minimum cost using only their milk. Neither is there anything to indicate that there were any lock-in issues.

${ }^{10}$ Ministère de l'agriculture 1929: 199. Contrary to what Allen and Lueck (2019: 330) seem to believe, nobody used stainless steel tanks, which are a post-World War II technology that has only become widespread since the 1960s (Robinson 2005: 132).
} 
Campllonch (1917: 199) stated that it cost Catalan cooperatives on average 0.5 pesetas to make one hectolitre of wine, while it cost small farmers between 0.75 and 1 peseta. Without citing any sources, he also said that the same proportions were to be found in France (p. 174). But, for three reasons, the real differences had to be lower.

First, Campllonch's calculations assume that small and medium-sized winegrowers had made relatively important investments to improve their wineries, so that a considerable portion of their production costs consisted in the interest and the amortisation of the investments. In fact, most small wine-growers continued to use the wooden presses and vats inherited from their ancestors. This was possible because the vast majority of the wine produced by all types of wine-growers was ordinary wine between 1907 and 1913 only 2.1 per cent of the wine from France was of a quality higher than that of ordinary table wine (XXX 2019).

Second, the key to lower production costs for cooperatives lay in wage cost savings (Galtier 1960, I: 374). But in 1927 it was pointed out that in order to take full advantage of this benefit it was necessary to produce at least between 15,000 and 20,000 hectolitres of wine per year (Congrès 1927: 352), when the average production of cooperative wineries was about 8,000 hectolitres (Marsais 1931: 49). Meanwhile, there were small, hand-operated metal presses which cost relatively little, allowed labour productivity to increase and were very well suited to the needs of small and, above all, medium-sized farms. In reference to Catalonia and to such presses, the engineer Raventós (1922: 44) said that 'you can see them everywhere'.

Third, in the wine sector new technologies allowed modest savings to be made on raw materials. It was common for cooperatives to use continuous mechanical presses powered by electricity that provided between 6 and 11 per cent more must per kilogram of grapes than traditional wooden presses. But a part of the additional must thus obtained was of bad quality, which penalised the price of the wine manufactured with it (XXX 2019). ${ }^{11}$

From a strictly economic point of view, in short, joining cooperative wineries was not at all attractive for large wine-growers, while for small and medium-sized winegrowers it was only moderately attractive. As a result, cooperative wineries only

\footnotetext{
${ }^{11}$ According to Henriksen (1999: 61), new technologies in the butter industry saved 25-30 per cent of milk per kilo of butter compared to farm processing, as well as raising its quality. Continuous presses consist of a horizontal tube with a flow of grapes, which are crushed by the pressure exerted by an Archimedes' screw. They were almost exclusively used to produce low-quality wine.
} 
flourished where some 'local' factor increased the attraction of belonging to them and, moreover, it was possible to finance their construction. For different reasons, in Mediterranean France and in Tarragona both circumstances converged.

5. Wine cooperatives in Mediterranean France. A quick glance

In addition to loans on very favourable terms and tax exemptions, French winegrowers who wanted to set up a cooperative winery also received non-refundable subsidies (Tardy 1929, Galtier 1960, I: 337). As a result, in 1929 France had 464 cooperative wineries, although their market share was only 8 per cent (Institut International d'Agriculture 1931: 200; Commission Internationale d'Agriculture 1931: 77). After state aid was increased in the 1930s (Galtier 1938, Marres 1939), by 1939 the figure had risen to 827 , with a market share of 16 per cent. But seven departments in the south accounted for 76 per cent of all the French cooperative wineries (Table 1).

$<<$ Table $1>>$

Cooperative scholars stress that the members were mostly small wine-growers for example, Roudié (1983) on Gironde and Rinaudo (1980) on Var. Four cooperatives that, according to Galtier (1960, I: 348), were typical of the department of Hérault accounted for, on average, 66 per cent of the municipality's wine-growers, but only owned 29 per cent of the vineyards and generated 26 of the wine. Table 2 compares the distribution of vineyard ownership in the departments of Hérault and Aude and in the 'L'Abri' cooperative in Lézignan, which was the cooperative winery with the most members in Aude. According to Pellegrin and Caillon (1939: 366), in Aude someone with fewer than 5 hectares was a small wine-grower and with more than 30 hectares one was a large wine-grower. The data available on other French cooperative wineries always point in the same direction: they were able to emerge and firmly establish themselves despite the fact that there were few wealthy farmers among their members. 
The conditions for access to state aid were the same throughout France and small wine-growers abounded in all its wine-growing regions (see Institut national de la statistique et des études économiques 1959, II), but cooperative wineries were concentrated in the south-east. This was the result of a problem that was not exclusive to the south-east but was felt there with special intensity, namely, the fact that many small and medium-sized wine-growers did not have enough room in their cellars to store the wine from all the grapes they produced (Simpson 2011: 71, Planas 2017). The vineyards destroyed by the phylloxera blight at the end of the nineteenth century were replanted with vines grafted onto American rootstocks that were more demanding in terms of fertilisers and other care, but yielded far more grapes per hectare. And the vineyards tended to descend from the slopes to the plains, which also increased yields (at the expense of the quality of the grape). Many small and medium wine-growers found that the vats had become too small, and the cooperatives were intended to extend rather than replace private wineries, so that members did not have to sell grape or must instead of wine (Berget 1902, Gervais 1913, Mandeville 1914, Gide 1926: 147). In the absence of an in-depth study, my assumption (which is inspired by Galtier 1960, I: 348) is that, in the departments shown in Table 1, the higher the percentage of vineyards owned by small wine-growers was, the higher the market share of the cooperatives would be. When data from the agricultural census of 1955 and correlations were used the assumption was not contradicted. The census does not indicate what percentage of vineyards were owned by small wine-growers, but both the correlation between the market share and the size of the average vine holding (Columns IV and V in Table 1) and the correlation between market share and the number of vine holdings over 50 hectares (Columns IV and VI) are negative and high (-0.78 and -0.86).

6. Wine cooperatives in pre-1936 Spain: hypotheses and evidence

In this section I review the hypotheses that have been formulated on the factors determining the creation of cooperative wineries in Spain, put forward an original hypothesis that grants great importance to the social conflict generated by the rabassa morta contract, and test them. 
The dependent variable of the regressions in Table 3 is the number of cooperative wineries per province. First Poisson models were used, but after finding that there was over-dispersion and suspecting that there was also an excess of zeros, zero-inflated negative binomial models were adopted. Vuong tests suggested that in Columns IIIa and IVa of Table 3 this was the correct option, but that in Columns I and II it was advisable to use standard negative binomial models.

Pan-Montojo (1993: 361, 366) advanced one of the key ideas of this article: as, in contrast to France, in Spain the state granted cooperative wineries little aid, they could only be built where the 'agrarian bourgeoisie' supported them. The intensity with which wealthy farmers in each province protected cooperatives (not only wine cooperatives, but the cooperative movement in general) can be measured using a proxy. As of 1904, the Bank of Spain offered agricultural cooperatives loans at 5 per cent. In exchange for the unlimited joint and several liability of all the members, obtaining them was relatively easy, but they presented a major disadvantage that did not exist in France: if the members did not include people who were individually very solvent, the bank rated the solvency of the cooperative as very low (even though it was made up of many farmers who, taken together, owned assets of great value) and was only willing to lend it small amounts. ${ }^{12}$ As a result, loans were usually borrowed only by cooperatives that had the backing of wealthy landowners. The independent variable Bank of Spain indicates how many cooperatives received them in each province. The assumption is that the more loans were granted, the more support large farmers gave to cooperatives and the more cooperative wineries there would be. But such loans were seldom granted directly to cooperative wineries. Normally they were given to sindicatos agrícolas, whose credit sections in turn sometimes granted loans for the creation of cooperative wineries. In Badajoz, the province where the cooperatives received the most money from the Bank of Spain, not a single cooperative winery was set up. The archives of the Bank of Spain contain lists of

\footnotetext{
${ }^{12}$ Even though the 785 members of a powerful sindicato agricola located in the Valencian orangegrowing area together had a patrimony valued at 40 million pesetas and asked for less than one million pesetas, the bank made it difficult for them to obtain the loan and in the end three large landowners acted as guarantors. Another sindicato agricola was only assigned a high credit rating thanks to the fact that one of its members was a 'rich landowner and wealthy merchant'. Archivo Histórico del Banco de España, DGS, 1799, 1994.
} 
cooperatives to which their provincial branches granted loans, or documents saying that none had been given. For some branches, however, there are no lists at all and it cannot be known with absolute certainty whether this is due to the fact that they have not been conserved or whether there were no loans. For this reason, in Table 1 Bank of Spain - which has the expected positive sign, but is not statistically significant has been used only in Column I.

Simpson (2000) argued that four circumstances favoured the appearance of winemaking cooperatives. The first is the strong specialisation in wine-growing. This is tested with vines, which is the percentage of the cultivated area dedicated to vineyards in each province. The hypothesis is confirmed, which is consistent with Hansmann's (1996: 136) argument that in areas that are highly specialised in some crop more members live in close proximity to one another and to the cooperative, thus increasing the possibility that the cooperative can be effectively monitored - because it was usual for cooperative wineries, unlike the majority supply cooperatives, to function democratically.

Second, the vine yields were high, because low yields would require an enormous surface area of vines to obtain sufficient grape to supply a medium-to-low capacity winery. In this case, a superficial examination of the data raised doubts about the goodness of the argument. In Columns I and II the variable has a positive sign and is not statistically significant. But when dummies are introduced in Columns IIIa and IVa to control for what happened in Catalonia the sign becomes negative and the coefficient is significant.

Third, few vine varieties were cultivated, because otherwise it was very difficult for cooperatives to measure the quality of the grape and to prevent members from behaving in an opportunistic manner. The hypothesis - initially formulated by Gide (1926: 92-93) and also taken up not only by Simpson but also by Fernández (2014b) is consistent with the claim by Hoffmann and Libecap (1991) and Hansmann (1996: 136) that the homogeneity of the product to be purchased from the members facilitates the emergence of marketing cooperatives. The lack of information makes it impossible to test this for Spain, but later when it is tested for the province of Tarragona (Table 4) it will be seen that, there, the greater the number of grape varieties was, the more cooperatives there were - partly because the cooperatives did not really have any serious problems when it came to measuring grape quality (XXX 2019). 
Lastly, small wine-growers abounded. As there is usually a strong correlation between the number of small wine-growers and the total number of vine holdings, which is the only one known, Vine holdings in 1962 is used, as 1962 is the first year for which information is available. The sign is positive, but there is no statistical significance. Because they are data for 1962, this and the variable mentioned below are only used in Column I.

Garrido (1996) showed that the sindicatos agrícolas tended to be strong where their membership included many medium-sized farmers. Obviously, this could only happen where there were a large number of medium-sized farmers. In order to test whether the existence of such farmers also favoured the creation of cooperative wineries, Average vine holding in 1962 and a second degree polynomial have been introduced. Indeed, the coefficient for the variable is positive and that of the squared variable is negative.

Various cliometric studies have employed human capital (measured by the illiteracy rate) and social capital (measured differently in each study) to explain the uneven spread of cooperatives (O’Rourke 2007a, Beltrán-Tapia 2012, Martínez-Soto, Martínez-Rodríguez and Méndez 2012, Fernández 2014a, Garrido 2014). This approach has also been used in Table 3, where illiteracy indicates the illiteracy rate in 1910. In a study on the spread of centrifugal milk separators in Ireland, O'Rourke (2007a: 406) found that illiteracy had a positive sign, as did Garrido (2014: 417) when analysing the factors determining the volume of fertilisers distributed by cooperatives in the Valencia region. In our case, making a prediction was a matter of heads or tails, because while Tarragona, the province with the most cooperative wineries, had a higher illiteracy rate (54 per cent) than the average in Spain (51) and in Catalonia (46), in Barcelona, Navarra, Valencia and Lleida, the following provinces in terms of the number of cooperatives, illiteracy was $35,34,63$ and 52 per cent. When the 'Catalan' dummies are introduced into Columns IIIa and IVa there is a change of sign, which was negative and now becomes positive, but the coefficients are never statistically significant.

Following the method designed by Beltrán-Tapia (2012), two common-pool resources are utilised as a proxy for social capital: common water (indicating the percentage of cultivated surface area in each province irrigated with collectively owned water) and commons (the percentage of total surface area in the province occupied by collectively-owned land). The underlying idea is that the presence of 
communal property implies a stock of social capital that facilitates cooperation to resolve any manifestation of the problem of collective action. The signs are always as expected. The fact that since before the nineteenth century the commons were present to a relatively small extent in Catalonia is almost certainly the reason why, again, the variable is only statistically significant in Columns IIIa and IVb.

Spring frosts are of great concern to wine-growers. While winter frosts usually cause little damage to the vines, which are then leafless and have little vegetative activity, if freezes occur during blooming in spring the harvest decreases or is lost altogether. Presumably, when the risk of spring frosts was high banks would prefer not to grant loans to build cooperative wineries, because they would have doubts about whether members could repay them on a regular basis. Therefore, the greater the risk of freezing in spring was, the fewer cooperative wineries there would be. In Spain blooming begins in March or April. When provincial mean temperatures in March and April were used successively, the coefficients had a positive sign and were statistically significant. Then altitude, which is the average height above sea level of each province and is strongly correlated with the average temperatures in March and April (-0.92 and -0.89), was used. Obviously, the sign became negative, but otherwise there was little change. AIC and BIC tests suggested that using altitude was the best option.

When analysing why most of the first cooperative wineries were in Catalonia, Planas (2016) underlined two factors. On the one hand, in many Catalan villages wine-growers created societies affiliated to the Vine-growers Federation of Catalonia ('Unió de Vinyaters de Catalunya'), which was led by large landowners and sought to put pressure on the public authorities to promote the export and consumption of wine (Planas 2013, 2017); according to Planas, this associative network facilitated the spread of cooperative wineries throughout the region. On the other hand, between 1914 and 1925 Catalonia enjoyed a certain degree of political autonomy and its authorities, contrary to what was being carried out in the rest of Spain, worked actively to foster the spread of cooperatives.

However, many of the societies belonging to the Vine-growers Federation of Catalonia were fictitious (Santesmases 1996: 236-41), and the appearance of similar federations in other Spanish regions (Castillo 1979: 294) did not lead to the creation of cooperative wineries in them. The lack of information on many provinces makes it impossible to introduce a variable in the regressions in Table 3 that measures the 
influence of this type of associationism - something that can be carried out later for the municipalities of Tarragona (Tables 5, 6 and 7). What is used in Table 3 are Sindicatos agrícolas created up to 1927 and Sindicatos agrícolas created up to 1927 existing in 1933. Although it was intended that specialised cooperatives would emerge from sindicatos agrícolas, the fact that most of the sindicatos agrícolas were shortlived did not help when it came to making predictions about the sign of the first of these variables, which was found to be negative. The positive sign of Sindicatos agrícolas created up to 1927 existing in 1933 was easily foreseeable.

As far as the Catalan policy of promoting cooperation is concerned, it was hampered by a lack of resources and only six cooperatives managed to receive loans (Casanovas 1996). Moreover, the years in which the Catalan autonomous government existed (1914-1925) partly overlapped with a period (1914-1920) of export euphoria due to the disturbances caused by the First World War. Between 1921 and 1925 the rate of creation of new cooperative wineries dropped sharply, so it is not clear whether what had influenced their creation prior to 1921 was the Catalan government's policy or the export euphoria. ${ }^{13}$ In fact, in a multi-country analysis Fernández (2014a) found evidence that exports favoured the strengthening of the processing and marketing cooperatives.

The effects of the Catalan government policy on cooperatives can only be tested imperfectly through the dummy Catalonia, which has a value of 1 for the four Catalan provinces and 0 for the rest of Spain. Introducing it in the regressions has served to verify the robustness of the rest of the variables and allows the model in Column IIIa to have a good predictive capacity (it predicts that in the four Catalan provinces an average of 19 cooperatives would be created and, in actual fact, 21 were set up; Table 4). But what Catalonia is capturing may be either the effects of the Catalan government's cooperative policy or any other factor that might be felt in Catalonia and not in the rest of Spain. In the rest of the article it will be show that what it mainly captures is the strong presence in Catalan vineyards of the rabassa morta contract, often simply called the rabassa contract (Garrido 2017a, 2017b, $2017 \mathrm{c}$ cites the literature on it at length).

\footnotetext{
${ }^{13}$ There were at least 10 groups of Catalan wine-growers that tried to build a cooperative winery in 1920 and abandoned the idea in 1921. This is known because they hired the same architect. https://www.coac.net/martinell/llistat_obres/llistat_complet.html
} 
In 1973 the renowned engineer Pascual Carrión (1973: 3) recalled that the first Spanish wine cooperative was founded in the 1890s 'by the rabassaires, that is to say, the sharecroppers of the vineyards' in a village in Tarragona. Rabassaires is the name given in Catalan to sharecroppers who grow vines under a rabassa contract. Of an emphyteutic nature, such contracts had been widely used since the eighteenth century in Girona and, above all, in Barcelona and Tarragona. In the early 1920s the rabassaires of Barcelona and Tarragona still cultivated between half and two thirds of all the vineyards (Instituto de Reformas Sociales 1923). ${ }^{14}$ In Lleida, the fourth Catalan province, rabassa contracts were rare.

When more than two thirds of the vines on a plot died, which is what happened without exception when phylloxera reached Catalonia, according to the law the rabassa contract was terminated. But in the 1890s the rabassaires were the protagonists of what the leading specialist on the subject called 'the most intense rural upheaval that Catalonia has known between the remences rebellion [that is, between the peasant uprising in the fifteenth century that led to the disappearance of servitude in Catalonia] and the [1936-39] civil war' (Giralt 1964: 66). As a result, their rabassa contracts remained de facto in force (Garrido 2017c).

As a first, and rudimentary, attempt to verify the influence that it exerted on the constitution of cooperative wineries, in column IVa Catalonia is replaced by rabassa morta, a three-level nominal variable which equals 0 in the provinces where the contract was not used, that is, Lleida and all the non-Catalan provinces; it is 1 for Girona, where it was used less than in Barcelona and Tarragona; and 2 for Barcelona and Tarragona. In Column IVb, the marginal effects at the mean show that the influence of some of the independent variables on the dependent variable is of a certain degree of importance: an increase of one hundred metres in mean altitude lowered the probability of an additional cooperative winery in the province by 26 per cent. But what should be emphasised above all is that rabassa morta allows the predictive capacity of the model to remain high (Table 4).

$<<$ Table 4 >>

For the same reason as mentioned with respect to Catalonia, this is not enough to

\footnotetext{
${ }^{14}$ Unfortunately, there are no municipal data or any accurate provincial data.
} 
prove the goodness of the theses that are defended here. But in the next two sections progress will be made in this direction, first by explaining what happened in Catalonia and then by using probit models and data from Tarragona, the only province for which it has been possible to gather disaggregated information at the municipal level. It is, however, unusually rich information.

\section{Sharecropping, conflict and cooperation in Catalonia}

Allen and Lueck (2019: 326) claim that the framework of farm organisation they put forward in 2002 helps to understand, among many other things, the reasons underlying 'the scarcity of tenancy contracts' in the vineyards. ${ }^{15}$ It is true that, in overall terms, tenancy contracts were used only to a relatively small extent in the vineyards. But four key nuances should be taken into account. First, their use was modest, but not negligible. In 1892 (and in 1979) in France, the only country for which overall information is available, 8.3 per cent (10 per cent in 1979) of the vineyards were cultivated by sharecroppers and another 8 per cent (19 per cent in 1979) by fixed-rent tenants (Garrido 2017a: 979, 981). Second, when disaggregated data are used instead of national averages large regional differences appear (Garrido 2017a: 979). Third, in the vineyards of France, Italy and Spain there were 'pockets of sharecropping', i.e. areas where sharecropping predominated. Fourth, sometimes the vineyards had been planted by the sharecroppers themselves, in exchange for which they acquired ownership rights over the vines - and sometimes also over the land (Garrido 2017a). In Catalonia, which had the largest pocket of wine sharecropping in Europe, rabassa contracts made this latter situation commonplace.

The Catalan sharecroppers that rioted in the 1890s wanted their land rights to remain in force and also improved contracts. They formed unions and a federation that was popularly known as the 'Rabassaires' Federation' ${ }^{16}$ It actively participated in elections and, although its social approaches were markedly left-wing, it was closely linked to the inter-class Federal Democratic Republican Party (López

\footnotetext{
${ }^{15}$ But in 2002 they believed that European vineyards were mostly cultivated by sharecroppers and at that moment their framework of farm organisation served to explain the reason why (Allen and Lueck 2002: 67).

${ }^{16}$ The official name was 'Federación de Trabajadores Agrícolas de la Región Española'. It brought together societies from 30 population centres in Tarragona and 28 in Barcelona (Mayayo 1995: 225).
} 
Estudillo 1989), ${ }^{17}$ which meant that in many villages sharecroppers' unions (and later their cooperatives) received support from wealthy Republican landowners.

Unlike sharecroppers in the province of Barcelona, those in Tarragona did not usually have wineries and had to sell their grape. Everything seems to indicate (Campllonch 1917: 38, Ferrer Alós 2015: 165, Planas 2016) that this is one of the main reasons why more cooperative wineries appeared in Tarragona (61) than in Barcelona (16), although the lack of detailed information prevents our regressions from including this variable.

Before the nineteenth century the sharecroppers of Tarragona did not have wineries because the province specialised in the export of eau-de-vie, which was distilled by traders who purchased grapes (Ferrer Alós 2015). When eau-de-vie then gave way to wine, the contracts sometimes established that the landlord would use all the grapes in his cellars and later hand over a part of the wine to the sharecropper (Ferrer Alós 2015). ${ }^{18}$ Still more often, sharecroppers continued to be grape sellers, but in some places they could not sell it to whomever they wanted because, by custom, the landlords had the right to buy it at the 'average price in the district' (Rendé 1923: 22-23; Mayayo 1986: 42).

In 1894 the small farmers' society in Barberà (a town of 1,354 inhabitants) went on strike so sharecroppers could freely dispose of their grape. ${ }^{19}$ The strike was successful and in the 1895 harvest the society rented a winery so the members could make wine together. It is the first known experience of wine cooperation in Spain. Thanks to the support of one of the biggest local landlords, who was a leading Republican politician, the society then built its own winery, which started operation in 1902 (Fuguet and Mayayo 1994).

Barberà's success triggered the spread of cooperative wineries throughout the neighbouring municipalities. Other small farmers' societies began to sell members'

\footnotetext{
${ }^{17}$ It was presided over by Francesc Pi i Margall, who had been one of the Presidents of the First Spanish Republic (1873-1874).

${ }^{18}$ Landlords also used this procedure in other parts of Europe, to avoid being cheated by the sharecropper when sharing out the grapes (Carmona and Simpson 2012). In return, the sharecroppers lost entrepreneurial freedom and they could not see what happened to the wine while it was in the landlord's cellar.
}

${ }^{19}$ Garrido (2017c) explains what the rabassaires' strikes were: if, for example they had to deliver $1 / 3$ of the harvest, they only worked $2 / 3$ of the holding and kept all their grapes. 
grapes and then made wine in rented wineries. They were unable to produce it at competitive prices and almost all of them soon abandoned that activity (Rendé 1923: 22-23). Many disappeared, but some of those that survived and several of those that subsequently appeared managed to build, sometimes many years later, a winery. ${ }^{20}$

In rural Spain elections were usually won by the 'official' candidates, who, with few exceptions, belonged to pro-monarchy parties. But during their mobilisation in the 1890s the rabassaires conquered the town halls of many municipalities and even some seats in the Congress of Deputies in Madrid (López Estudillo 1989). Since allowing the cooperatives to be controlled exclusively by leftist rabassaires and republican landowners was very dangerous from a social and electoral point of view, groups of non-republican landlords also set up cooperative wineries, which often displayed a great ability to attract small landowners and sharecroppers. In Alió (636 inhabitants), one of the first villages where this happened, the five richest members acted as guarantors for the bank loan taken out to build the winery and at the same time all the members signed a notarial document undertaking to be joint and severally responsible for repaying the loan (Ibarra 1998). In many other places similar procedures were used. ${ }^{21}$ According to Planas (2016), the fact that in the province of Barcelona the conflict in the vineyards was even greater than in Tarragona hampered collaboration between sharecroppers and landlords and made it more difficult to create cooperative wineries. ${ }^{22}$

In 25 villages in Tarragona only one cooperative winery appeared. But 18 villages (including Barberà) had two - one cooperative for the 'poor' and another for the 'rich'. From the technical and economic perspective, ideally there would have only been one, because the villages with two cooperatives were usually small (mean = 2,364 inhabitants; median $=1,470 ;$ minimum $=662$ ). When there was only one it was

\footnotetext{
${ }^{20}$ Gavaldà (1989) reproduces the rules of one such society, that of Valls, which began to market the members' grapes in 1897, made wine in rented cellars as of 1898 and built its own facilities in 1913. In 1919 a rival cooperative winery appeared in the municipality - the 'cooperative of the rich'.

21 Rendé (1923: 123). The landlords who were members of the same cooperative as their sharecroppers had access, as a by-product, to an attractive advantage: since the wine from all the grapes of the holding was manufactured by the cooperative, the sharecroppers could not cheat them when distributing the harvest (Santesmases 1996: 101).

${ }^{22}$ The relationship between conflict and cooperative wineries would therefore have an inverted Ushape. But the conflict was only greater in Barcelona in the 1920s and 1930s, so it is possible that the greater presence of cooperatives in Tarragona before then acted as a factor of social pacification.
} 
usually because the 'poor' or the 'rich' in the municipal area had suggested creating it and the other collective joined the initiative (Fuguet 1987).

As many landlords wanted to continue making wine in their wineries, the Catalan cooperatives did not usually oblige their members to hand over all the grapes they produced, but instead the kilos that were agreed upon in each case (XXX 2019). ${ }^{23}$ Moreover, the sales of wine were not usually negotiated by a single person or the board of directors, but by committees which could have up to 16 members. And the final decision was often taken by the general assembly. The more people there were involved in making the decision, the more difficult it was to quickly reach an agreement and keep it secret. But cooperative members included the poor and the rich, landlords and sharecroppers, people who were highly dependent on the cooperative and people who depended little. The sale committees were usually made up of representatives of all of them, because heterogeneity always forces cooperatives to pay the price (Hansmann 1996, 1999).

But in one important aspect there was homogeneity. The birth of the Irish cooperative movement coincided with the struggles for land ownership and national independence. This led to the spread of cooperatives, which were set up initially by 'patriotic aristocratic reformers' (O'Rourke 2007a: 1370), and at the same time made it difficult for them to develop because they were issues that divided Irish society (Ó Gráda 1979, O’Rourke 2007a). In Catalonia the spread of cooperative wineries coincided with that of the pro-Catalan movement - which was initially of a 'regionalist' nature but in the twenty-first century has evolved towards proindependence. In the 1890s the rabassaires looked upon it coldly, but then joined it (Balcells 1968, Hansen 1969, Pomés 2000). Before the Franco dictatorship prohibited it, the Catalan cooperative wineries (those of both the 'poor' and the 'rich') commonly used the Catalan language in their functions, internal documents and publications when using the Catalan language was seen by many Spaniards as an attack against Spanish. I have not been able to find any evidence showing that the existing consensus in Catalan rural society in favour of the Catalan culture serves to explain why more cooperative wineries were created in Catalonia than in the rest of Spain, but it is clear that, unlike in Ireland, in Catalonia the national question did not curb the consolidation of cooperatives.

\footnotetext{
${ }^{23}$ This is one of the reasons why they had only a 40 per cent market share in Tarragona.
} 


\section{Tarragona}

The data will now come from 180 municipalities (out of 185) in Tarragona where vines were grown. First, probit models were used to find out what determined the likelihood of wine-making cooperatives emerging in those areas (Table 5).

Six explanatory variables coincide with the variables that already appeared in Table 3: Bank of Spain, vines, illiteracy, common water, commons and altitude. Except for altitude, all of them are statistically significant. Four of them have the same positive signs as in Columns IIIa and IVa in Table 3: Bank of Spain, vines, common water and commons. The fact that 41 out of 198 Spanish cooperatives that received loans from the Bank of Spain were from Tarragona is evidence of the support of wealthy farmers in Tarragona for cooperatives. The 41 cooperatives in Tarragona that received loans were in 29 municipalities. Only 17 of them built cooperative wineries but when Bank of Spain is 1 the probability of villages having a cooperative winery increases by 25 per cent (Column IIIb in Table 5).

Illiteracy now has a negative sign (and statistical significance). Therefore, although the fact that Tarragona's illiteracy rate was above the average for Spain and Catalonia did not prevent half of Spanish cooperative wineries from being set up in Tarragona, in the municipalities in the province where the illiteracy rate was higher there was less likelihood of wine-growers cooperating - an increase by one percentage point in the illiteracy rate causes a 0.6 per cent drop in the probability of a municipality having a cooperative winery (Column IIIb in Table 5).

Altitude, which in the regressions on Spain had a negative sign, now has changing, but mostly positive, signs and is no longer statistically significant. This is the result of the fact that rabassa contracts tended to be used for vineyards located in mountainous areas (Garrido 2017a).

While in Tarragona the number of small landowners was relatively high and sharecroppers were frequently at the same time owner-cultivators, in Barcelona the opposite occurred. According to Planas (2016), this is another of the reasons for there being more cooperative wineries in Tarragona than in Barcelona. Only some dispersed information is available for Barcelona (Soler-Becerro 2019), but a 1918 tax register from Tarragona made it possible to use the variables land owners, Gini Index 
and middle-sized owners in Table $5 .^{24}$

To introduce land owners, a second degree polynomial was used again, because the fragmentation of ownership was especially high in the municipalities in the south of the province, where sharecropping was unusual. Moreover, there is a strong correlation between the number of landowners and the number of inhabitants in the municipalities $(r=0.76)$. In addition to their economic functions, the wine-making cooperatives acted as social centres. Although in municipal areas with few inhabitants this second function became more important, in very small villages it was impossible to get the minimum number of members (land owners or sharecroppers) to set them up. But from a certain point onwards the growth in the number of landowners / inhabitants would reduce the likelihood of their emergence. This is in fact what happened according to Table 5.

The coefficient of Gini Index is positive, although it is never statistically significant. It is positive because in Tarragona the greater inequality in land ownership was usually linked to a greater use of sharecropping contracts (SolerBecerro 2019: 121-123). The negative sign of middle-sized owners (i.e. the percentage of owners with an assigned taxable base of between 75 and 200 pesetas) is more unexpected. As the variable is not statistically significant and removing it had little effect on the rest of the variables, it was only used in Column I. ${ }^{25}$

Rabassaires, a dummy which is 1 in the 30 municipal districts with societies belonging to the 'Rabassaires' Federation' in the 1890s, raises the likelihood of the municipality having a cooperative winery by 32 per cent (Column IIIb in Table 5). The really strong ones, however, are the joint marginal effects of Rabassaires and Bank of Spain. All else being constant, when both dummies are 0 the probability that the dependent variable is 1 is 17 per cent, and when both are 1 it is 77 per cent.

In contrast, Vine-growers Federation of Catalonia and Agrarian Federation of Catalonia ('Federació Agrària Catalana-Balear') are not statistically significant. The first of these federations is the one to which Planas (2016) attributed a great effect in the appearance of cooperative wineries. It had delegations in 65 villages in Tarragona (Planas 2013: 53, Santesmases 1996: 236-241). The other federation, which was also

\footnotetext{
${ }^{24}$ The register only shows land owners. Consequently, no landless sharecropper is in it nor can we know the number of small and middle-sized owners who were also sharecroppers. It allows us to know how many people owned land, but not whether they owned vineyards.

${ }^{25}$ Its correlation with Gini Index is low (0.15) and with landowners it is very low (-0.003).
} 
controlled by wealthy landowners, claimed to promote technical improvements and 'social peace' and held several congresses on viticulture. In 1909 it had societies in 42 villages in Tarragona. ${ }^{26}$

The last explanatory variable in Columns I and II in Table 5, $\mathrm{km}$ to the train station, indicates how many kilometres the centre of each village was from the nearest railway station. Merchants went to the villages to buy wine and then sent it by road (using mainly carts) to a railway station. Presumably, when the supply of wine was greater than the demand (Pujol 1984) they would tend to buy wine from the areas closest to the stations and thus in the more distant areas the incentives to create cooperatives would be greater. The variable is statistically significant and its marginal effects are quite considerable - the average distance to the train was $8.2 \mathrm{~km}$ and the maximum was $45 \mathrm{~km}$. Normally, cooperatives paid the cost of transporting the wine from their facilities to the railway, but their costs were lower than those of a small wine-grower who might have sought to do the same alone.

For the additional explanatory variables that appear in Column IIIa there is only information on 114 municipal districts. It is easy to understand why average alcohol content of wine has a negative sign: as merchants preferred wine with a high alcohol content (XXX 2019), the higher the average alcohol content of the wine from a municipal district was, the less likely it was that wine-growers would cooperate.

According to a hypothesis that has already been mentioned above, in the places where few vine varieties were grown it was easier for cooperatives to be created. But number of grape varieties grown in the municipalities of Tarragona in $1915($ mean $=6$, median $=5$, maximum $=26$, minimum $=1)$ helps to reject that argument. In fact, making wine with many different varieties of grape offered various advantages. The virtues and defects of some varieties could be compensated by the virtues and defects of others. It was easier to achieve a uniform type of wine every year. And, as each variety matures at different moments, the harvest could last longer and it was more difficult for part of the members' harvest to be spoilt because of the cooperative's inability to process all the grape in a short time (Piqueras 2009). When number of grape varieties was replaced by dominant varieties $($ mean $=3.6$, median $=$ 3 , maximum $=17)$ the coefficient was still positive and significant.

\footnotetext{
${ }^{26}$ If rabassaires is eliminated from the regressions and the other two variables are introduced one at a time, they are still not statistically significant.
} 
Some municipal areas produced only white wine, which can be made with practically any grape variety (because during production the peel, which contains the tannins that give wine its red colour, is separated from the must before fermentation). Other municipal areas produced only red wine. The coefficient of this last variable is not statistically significant but producing only white wine meant a statistically significant 36 per cent increase in the likelihood of a cooperative being set up in the municipal area. There are two possible reasons for this. Firstly, continuous mechanical presses, as explained, were the ones cooperatives preferred and produced more satisfactory results with grape used to produce white wine; moreover, cooperatives that produced only white wine needed to invest less to build their facilities, because the fermentation tanks did not need to be as big and could also be used as storage tanks. Secondly, there may be a relation with the type of market for which the white and red wines from Tarragona were mainly intended: while the white wine was exported to the European market (Marcilla 1922: 135), the red wine was mainly consumed in the Catalonian and Spanish markets.

The fact that the coefficient of Priorat (a dummy equal to 1 for municipal areas in this district) has a positive sign and is statistically significant seems to point to the second possibility, because wine from Priorat was red and mainly exported. Its marginal effect is so high (Column IIIb) because the destruction caused by phylloxera gave rise to a strong migratory movement in Priorat and, for it to help retain sharecroppers, wealthy landowners were particularly prone to participate in the cooperative movement.

$<<$ Table $6>>$

As there could be two, one or no cooperative winery in the villages of Tarragona, in Table 6 ordered probit models have been used. Results are similar to those shown in Table 5, except that illiteracy is no longer statistically significant. In Column IIa, inhabitants have been used instead of land owners, which results in an increase in the R-squared and the relative quality of the model; this is probably due to the fact that inhabitants is able to capture the varying presence of landless sharecroppers in the municipalities.

In 17 municipalities modernist-style cooperative wineries were built, some of 
which were magnificent works of art. ${ }^{27}$ They were more expensive to build than wineries that were not meant to reflect any artistic intention and, in the best of cases, were equally functional, but served to remind the rest of the local society of the magnitude of the power of the group of neighbours who financed their construction. Most emerged in villages with two cooperatives and belonged to the cooperative of the 'rich'. The curiosity to know what factors determined their appearance (Table 7) has led to a striking discovery: greater inequality in land ownership (Gini Index) increased in a statistically significant manner the likelihood of a modernist style winery being built in the municipality; the increase in the social capital (in a statistically significant way for common water and a non-statistically significant manner for commons) and the decrease in illiteracy (in a non-statistically significant way), however, made that probability diminish.

$$
<<\text { Table } 7>>
$$

\section{Conclusions}

In some places the sharecroppers and landlords did not share the grapes, but instead the wine, after it had been manufactured in the cellars of the landlord (Simpson 2000, Carmona and Simpson 2012). This has sometimes been seen as a form of cooperation between landlords and sharecroppers. But cooperation is by definition a voluntary act and it is difficult to know whether sharecroppers participated in such dealings of their own free will. Perhaps when most of the sharecroppers in Burgundy stopped making wine on the landlord's premises, according to one author due to 'selfishness' (Gondry du Jardinet 1874: 77), they were simply escaping an imposition.

In Spain the first cooperative wineries were created by sharecroppers (rabassaires) who were indeed escaping an imposition. It was common for the sharecroppers in Tarragona not to have wineries and to sell their grapes to traders or to their landlords. When the latter occurred, sometimes sales were compulsory and were made at the non-negotiated 'average price in the district'. The first Spanish cooperative winery was set up by sharecroppers who until then had been subject to

\footnotetext{
${ }^{27}$ http://www.catalunya.com/ruta-dels-cellers-modernistes-24-1-15?language=en

The author of most of the plans was the architect Cèsar Martinell, a disciple of Antoni Gaudí.
} 
such sales and who, for political reasons, were supported by wealthy people. As stated by Hansmann (1999: 390) - who refers to cases in which market power is held by a firm - the landlords who bought grapes enjoyed 'simple market power' and their sharecroppers had an incentive to own a cooperative 'and thereby avoid price exploitation'. The example of the pioneers was followed by the sharecroppers in other municipalities. For social and political reasons, groups of landlords with a conservative political inclination reacted by also creating cooperative wineries, which were open to all types of farmers. The result was that 61 of the 125 cooperative wineries built in Spain before 1936 were in Tarragona, where only 6 per cent of the Spanish vineyards were located.

Many social scientists view with scepticism the possibility that in contexts of strong social heterogeneity there could be 'vertical' cooperation between individuals. 'Cooperation among unequals is problematic', stated for example Boix and Posner (1998: 688). Olson (1965: 33-36) had a great insight on the issue. When noncooperation causes great harm to the more fortunate, they will bear the cost of building the structures necessary for cooperation to take place alone and even allow the less fortunate to free-ride. Olson, however, did not consider this to be true cooperation, but rather 'the exploitation of the rich by the poor'. Yet the 'rich' of Tarragona in no way allowed themselves to be 'exploited'. They frequently only promised to bring part of their grapes to the cooperative, using the rest to make wine in their private cellars, and they never allowed the other members to free-ride. But, like these, they were linked through unlimited joint and several liability to the loans granted to build the facilities and they were also under surveillance to prevent them from breaking the rules (XXX 2019), which led to there being 'real' cooperation.

The specific reason why the first Spanish cooperative wineries appeared is a little more than a (beautiful) anecdote. The essence of the matter is that, for social and political reasons, in a part of Catalonia cooperative wineries managed to attract wealthy landowners, which in Spain (but not in France, due to state intervention) was crucial for them to emerge.

\section{Acknowledgements}

This article has benefited from financial assistance from the Generalitat Valenciana (AICO/2018/130) and the Spanish Ministry of Science, Innovation and Universities 
(PGC2018-095529-B-I00). Previous versions of the article were presented in seminars at Universitat de València, EHESS in Paris, and Universidad de Zaragoza. The author is grateful to the participants at all these seminars for their comments. He also appreciates the helpful comments from two anonymous referees and editor Claude Diebolt, and is indebted to Pere Audí, Salvador Calatayud, Ernesto Clar, Lluís Carda, Fernando Collantes, Rosa Congost, Domingo Gallego, Ricard Garcia Orallo, José M. Martínez Carrión, José M. Lana, Francisco Medina, Enric Morellà, Juan Piqueras and Josep Santesmases.

\section{Appendix 1. Descriptive statistics of Table 3}

\begin{tabular}{lrrrrrr}
\hline & $\begin{array}{r}\text { Cooperative } \\
\text { wineries }\end{array}$ & $\begin{array}{r}\text { Bank of } \\
\text { Spain }\end{array}$ & $\begin{array}{r}\text { Vines } \\
\%\end{array}$ & $\begin{array}{r}\text { Yields } \\
\text { hl/ha }\end{array}$ & $\begin{array}{r}\text { Vine } \\
\text { holdings }\end{array}$ & $\begin{array}{r}\text { Average } \\
\text { vine holdings }\end{array}$ \\
\hline Mean & 2.8 & 4.4 & 7.8 & 16.8 & $15,135.2$ & 1.8 \\
Median & 0.0 & 0.0 & 4.9 & 12.6 & $10,717.0$ & 1,2 \\
Std. Dev. & 9.4 & 9.0 & 9.6 & 11.2 & $13,519.5$ & 1.7 \\
Min. & 0.0 & 0.0 & 0.3 & 7.5 & 862.0 & 0.1 \\
Max. & 61.0 & 41.0 & 56.5 & 51.1 & $58,550.0$ & 9.6 \\
\hline
\end{tabular}

\begin{tabular}{|c|c|c|c|c|c|c|}
\hline & $\begin{array}{r}\text { Illiteracy } \\
\% \\
\end{array}$ & $\begin{array}{r}\text { Common } \\
\text { water \% } \\
\end{array}$ & $\begin{array}{r}\text { Commons } \\
\% \\
\end{array}$ & $\begin{array}{r}\text { Altitude } \\
10^{2} \mathrm{~m} \\
\end{array}$ & $\begin{array}{r}\text { SA up to } \\
1927 \\
\end{array}$ & $\begin{array}{r}\text { SA up to } 1927 \\
\text { existing in } 1933 \\
\end{array}$ \\
\hline Mean & 40.6 & 4.3 & 14.9 & 6.7 & 125.9 & 47.8 \\
\hline Median & 44.0 & 1.6 & 12.8 & 7.1 & 103.0 & 40.0 \\
\hline Std. Dev. & 17.4 & 6.2 & 11.3 & 2.8 & 75.6 & 37.2 \\
\hline Min. & 8.0 & 0.0 & 0.7 & 1.4 & 16.0 & 5.0 \\
\hline Max. & 69.0 & 27.1 & 50.1 & 11.3 & 352.0 & 160.0 \\
\hline
\end{tabular}

Sources:

Cooperative wineries: Flamarique (1914), Campllonch (1917), Piqueras (2006, 2010) and Planas (2016).

Vines, Yields, and Commons: Grupo de Estudios de Historia Rural (1991).

Vine holdings in 1962 and Average vine holding: Instituto Nacional de Estadística (1962).

Bank of Spain: Archivo Histórico del Banco de España, DGS, 2001, 84-14.

Sindicatos agrícolas created up to 1933 and SA created up to 1933 existing in 1933: 
Garrido (1996).

Illiteracy: Vilanova and Moreno (1992).

Common water: Ministerio de Fomento (1918).

\section{Appendix 2. Descriptive statistics of Tables 5, 6 and 7}

\begin{tabular}{lrrrrrr}
\hline & Vines & Illiteracy & Common & Commons & Altitude & Land owners \\
& $\%$ & $\%$ & Water $\%$ & $\%$ & $10^{2} \mathrm{~m}$ & $10^{2}$ \\
\hline Mean & 45.9 & 50.7 & 3.9 & 2.9 & 2.9 & 5.7 \\
Median & 48.6 & 49.3 & 1.7 & 0.0 & 2.4 & 3.7 \\
Std. Dev. & 25.3 & 13.4 & 6.5 & 9.0 & 2.3 & 7.0 \\
Min. & 2.0 & 19.2 & 0.0 & 0.0 & 0.2 & 0.7 \\
Max. & 100.0 & 83.7 & 59.1 & 55.2 & 9.9 & 72.3 \\
\hline
\end{tabular}

\begin{tabular}{lcrrrr}
\hline & $\begin{array}{r}\text { Inhabitants } \\
10^{3}\end{array}$ & $\begin{array}{r}\text { Gini } \\
\text { Index } \%\end{array}$ & $\begin{array}{r}\text { Km to } \\
\text { the train }\end{array}$ & $\begin{array}{r}\text { Alcohol } \\
\text { (grades) }\end{array}$ & $\begin{array}{r}\text { Grape } \\
\text { varieties }\end{array}$ \\
\hline Mean & 1.8 & 45.3 & 8.2 & 13.0 & 6.1 \\
Median & 1.0 & 45.2 & 6.0 & 13.0 & 5.0 \\
Std. Dev. & 3.4 & 8.8 & 8.9 & 1.7 & 3.9 \\
Min. & 0.09 & 27.5 & 0.0 & 6.5 & 1.0 \\
Max. & 28.1 & 78.9 & 45.0 & 16.0 & 26.0 \\
\hline
\end{tabular}

Sources:

Vines and Common water: Morera (1913).

Bank of Spain: Archivo Histórico del Banco de España, DGS, 2001, 84-14.

Illiteracy and Inhabitants: Instituto Geográfico y Estadístico (1913).

Commons: Catálogo (1901), and Gaceta de Madrid, 22 September1897.

Land owners and Gini Index: Arxiu Històric de Tarragona, Hisenda, Repartiments, 3489.

Rabassaires and Agrarian Federation of Catalonia: Mayayo (1995: 255-8).

Km to the train: Riera (1908).

Average alcohol content of wine, Grape varieties, Only white wine, and Only red wine: Oliveras (1915). 


\section{Reference list}

Allen DW, Lueck D (2002) The nature of the farm: Contracts, uncertainty, and organization. MIT Press, Cambridge.

Allen DW, Lueck D (2019) The organization of vineyards and wineries. In Alonso A, Cardebat JM, Corsi A (ed) The Palgrave handbook of wine industry economics. Palgrave Macmillan, 325-337.

Augé-Laribé M (1926) Syndicats et coopératives agricoles. Armand Colin, Paris.

Balcells A (1968) El problema agrari a Catalunya (1890-1936): la qüestió rabassaire. Nova Terra, Barcelona.

Barral P (1968) Les agrariens français: de Méline à Pisani. Armand Colin, Paris.

Beltrán-Tapia F (2012) Commons, social capital, and the emergence of agricultural cooperatives in early twentieth century Spain. European Review of Economic History 16(4): 511-28

Berget A (1901) La situation économique de la viticulture allemande. Bureaux de la 'Revue de Viticulture', Paris.

Berget A (1902) La coopération dans la viticulture européenne. Devos, Lille.

Boix C, Posner DN (1998) Social capital: Explaining its origins and effects on government performance. British journal of political science 28(4): 686-693.

Campllonch I (1917) Cellers cooperatius de producció i venda. Giró, Barcelona.

Carmona J, Simpson J (2012) Explaining contract choice: vertical coordination, sharecropping, and wine in Europe, 1850-1950. Economic History Review 65(3): 887-909.

Carrión P (1973) Problemas de la cooperación agrícola. Estudios Cooperativos 29: 316.

Castillo JJ (1979) Propietarios muy pobres. Sobre la subordinación política del pequeño campesino en España. Ministerio de Agricultura, Madrid.

Catálogo (1901) Catálogo de los montes y demás terrenos forestales exceptuados de la Desamortización. Minuesa, Madrid.

Cleary MC (1989) Peasans, politicians and producers. The organisation of agriculture in France since 1918. Cambridge UP, Cambridge.

Clique H (1931) Les caves coopératives de vinification en Bourgogne. Recueil Sirey, Paris. 
Colvin CL, McLaughlin E (2014) Raiffeisenism abroad: why did German cooperative banking fail in Ireland but prosper in the Netherlands? Economic History Review 67(2): 492-516.

Comission International d'Agriculture (1931) L'État actuel de la coopération agricole dans les différents pays. Paris.

Confédération nationale des coopératives vinicoles (1955) Annuaire National des Caves Coopératives de France, 1955-1956. Paris.

Congrès (1927) XIV Congrès national de la mutualité, de la coopération et du crédit agrícoles. L’indépendent, Perpignan.

Dirección General de Agricultura (1934) Censo estadístico de sindicatos agrícolas y Comunidades de Labradores. Madrid.

Fay GR (1920) Co-operation at home and abroad. King \& Son, London.

Federico G (2008) Feeding the world. An agricultural history of agriculture, 1800200. Princeton UP, Princeton.

Fernández E (2014a) Trust, religion, and cooperation in western agriculture, 1880 1930”. Economic History Review 67(3): 678-98

Fernández E (2014b) Selling agricultural products: farmers' co-operatives in production and marketing, 1880-1930. Business History 56(4): 547-68.

Fernández E, Simpson J (2017) Product quality or market regulation? Explaining the slow growth of Europe's wine cooperatives, 1880-1980. Economic History Review 70(1): 122-142.

Ferrer Alós Ll (2015) Vi per cremar, vi per beure. Dues vitivinicultures a Catalunya. In Colomé et al (eds) Vinyes, vins i cooperativisme vitivinícola a Cataluny. Abadia de Montserrat, Barcelona, pp. 147-76.

Flamarique V (1914) Cooperativas para la venta de vinos. Su organización y funcionamiento. Historial de las existentes en España. In Congreso Nacional de Viticultura. Imprenta Provincial, Pamplona, pp. 109-124.

Fuguet J (1987) El celler del sindicat agrícola de Rocafort de Queralt. Aplec de Treballs 8: $39-58$

Fuguet J, Mayayo A (1994) El primer celler cooperatiu de Catalunya. Generalitat de Catalunya, Barcelona.

Galtier G (1938) Les coopératives viticoles dans le département de l'Hérault en 1938. Bulletin de la Société Languedocienne de Géographie 9(1): 33-50. 
Galtier G (1960) Le vignoble du Languedoc méditerranéen et du Roussillon, I. Graille \& Castelnau, Montpellier.

Garrido S (1996) Treballar en comú. El cooperativisme agrari a Espanya, 1900-1936, Alfons el Magnànim, Valencia.

Garrido S (2007) Why did most cooperatives fail? Spanish agricultural cooperation in the early twentieth century. Rural History 18(2): 183-200.

Garrido S (2014) Plenty of trust, not much cooperation. Social capital and collective action in early twentieth century Spain. European Review of Economic History 18(4): 423-432.

Garrido S (2017a) Sharecropping was sometimes efficient: sharecropping with compensation for improvements in European viticulture. Economic History Review 70(3): 977-1003

Garrido S (2017b) “¿Desnaturalizados rabassers? La rabassa morta catalana antes de la filoxera". Ayer 107: 155-182.

Garrido S (2017c) El fruto de la inseguridad. Vino, contrato óptimo y derechos de propiedad en Cataluña (1898-1935). Revista de Historia Económica - Journal of Iberian and Latin American Economic History 35(3): 415-443.

Garrido S (2019) Cooperatives, opportunism and quality product: why the early Spanish cooperative wineries produced ordinary wine. Business History, DOI: 10.1080/00076791.2019.1685504.

Gavaldà A (1988) L'associacionisme agrari a Catalunya. El model de la Societat Agrícola de Valls. Biblioteca d'Estudis Vallencs, Valls.

Gervais M (1913) La coopération en viticulture. Laveur, Paris.

Gide C (1926) Les associations coopératives agrícoles. Association pour l'Enseignement de la Coopération, Paris.

Giralt E (1964) El conflicto rabassaire y la cuestión agraria en Cataluña hasta 1936. Revista de Trabajo 3: 51-72.

Gondry du Jardinet J (1874) Une agréable visite aux grands crus de France et de l'étranger. Soye, Paris.

Grupo de Estudios de Historia Rural (1991) Estadísticas históricas de la producción agraria española, 1859-1935. Ministerio de Agricultura, Madrid.

Hansen EC (1969) The state and land tenure conflicts in rural Catalonia. Anthropologhical Quarterly 42(3): 214-243. 
Hansmann H (1996) The ownership of enterprise. Harvard University Press, Cambridge (Mass.)

Hansmann H (1999) Cooperative firms in theory and practice. Finnish Journal of Business Economics 48(4): 387-403.

Henriksen I (1999) Avoiding lock-in: cooperative creameries in Denmark, 18821903. European Review of Economic History 3(1): 57-78.

Hoffmann E, Libecap G (1991) Institutional Choice and the Development of U.S. agricultural Policies in the 1920s. Journal of Economic History 51(2): 397-411. Ibarra R (1998) El sindicat agrícola d'Alió i el seu celler cooperatiu. Quaderns de Vilaniu 34: 43-85

Institut International d'Agriculture (1931) La coopération agricole, Bestetti \& Tumminell, Rome.

Institut national de la statistique et des études économiques (1959) Récensement géneral du vignoble de 1955. I: Caracteristiques génerales des exploitations. II: Premiers résultats par région agricole. Impremerie Nationale, Paris.

Instituto de Reformas Sociales (1923) La 'rabassa morta' y su reforma. Minuesa, Madrid.

Instituto Geográfico y Estadístico (1913) Censo de la población de España el 31 de diciembre de 1910. Madrid.

Instituto Nacional de Estadística (1962) Censo agrario de España. Madrid.

King C (1996) The early development of agricultural cooperation: some French and Irish comparisons. Proceedings of the Royal Irish Academy: Archaeology, Culture, History, Literature 96C(3): 67-86.

López Estudillo A (1989) Federalismo y mundo rural en Cataluña (1890-1905).

Historia Social 3: 17-32.

Mandeville L (1914) Etude sur les sociétés cooperatives de vinification du Midi de la France. Douladoure-Privat, Toulouse.

Marcilla J (1922) Vinificación en paises cálidos. Calpe, Madrid.

Marres P (1939) Les coopératives de vinification dans le Bas-Languedoc. Annales de Géographie 274: 430-432.

Marsais P (1939) Les caves coopératives en France (Paris).

Martínez-Soto A, Martínez-Rodríguez S, Méndez I (2017) Spain's development of rural credit cooperatives from 1900 to 1936: the role of financial resources and formal education. European Review of Economic History 16(4): 449-468. 
Mayayo A (1986) La Conca de Barberà 1890-1936: de la crisi agrària a la Guerra Civil. Centre d'Estudis de la Conca de Barberà, Montblanc.

Mayayo A (1995) De pagesos a ciutadans. Cent anys de sindicalisme i cooperativisme agraris a Catalunya. Afers, Catarroja.

McLauglhin E (2015) Competing forms of cooperation? Land League, Land War and cooperation in Ireland, 1879 to 1914. Agricultural History Review 63(1): 81-112.

Medina-Albadalejo F (2016) Intervención estatal del sector vinícola español durante el franquismo: las bodegas cooperativas. In Girbal-Blacha N, López MI, De Mendonça SR (ed) Agro y política a uno y otro lado del Atlántico. Franquismo, salazarismo, varguismo y peronismo. Imago Mundi, Buenos Aires, 32-52.

Medina-Albadalejo F, Planas, J (2020) Las Bodegas cooperativas y la comercialización del vino en España. Investigaciones de Historia Económica 16: 23-34.

Ministère du commerce (1939) Annuaire statistique, 1939. Paris.

Ministère de l'agriculture (1911) Dix ans de crédit agricole (1900-1909). Imprimerie Nationale, Paris.

Ministère de l'agriculture (1917) Le crédit agricola. Imprimerie Nationale, Paris.

Ministère de l'agriculture (1929): Enquête Agricole 1929. Monographie agricole du département du Var. Typed (Bibliothèque Claude Bernard, Paris).

Ministère de l'agriculture (1937). Statistique agricole de la France. Annexe a l'enquête de 1929. Monographie agricole du département de l'Hérault. Paris.

Ministerio de Fomento (1918) Medios que se utilizan para suministrar el riego a las tierras. Madrid.

Morera E (1913) Geografia general de Catalunya. Província de Tarragona. Albert Martín, Barcelona.

Ó Gráda C (1977) The Beginnings of the Irish Creamery System, 1880-1914. Economic History Review 30(2): 284-305.

Oliveras C (1915) Datos para un avance sobre la viticultura de la provincia de Tarragona. Navas, Reus.

Olson M (1965) The logic of collective action. Harvard UP, Harvard (Mass.)

O'Rourke KH (2007a) Culture, Conflict and Cooperation: Irish Dairying Before the Great War. The Economic Journal 523(117): 1357-1379.

O'Rourke KH (2007b) Property rights, politics and innovation: creamery diffusion in pre-1914 Ireland. European Review of Economic History 11(3): 395-417. 
Pan-Montojo J (1993) La bodega del mundo. La vid y el vino en España (1800-1936). Alianza Editorial, Madrid.

Pellegrin V, Caillon P (1939) L'agriculture du département de l'Aude en 1939.

Gabelle, Carcassonne.

Piqueras J (2006) Las bodegas cooperativas en España. El proceso de difusión espacial. Cuadernos de Geografía 80: 194-232.

Piqueras J (2009) Campo Arcís. Cooperativismo y viticultura. Cooperativa San Isidro, Campo Arcís.

Piqueras J (2010) De las plagas americanas al cooperativismo en España. Vinseum, Vilafranca del Penedès.

Planas J (2013) Viticultura i cooperativisme. La comarca d'Igualada, 1890-1939. Abadia de Montserrat, Barcelona.

Planas J (2016) The emergence of winemaking cooperatives in Catalonia. Business History 58(2): 263-281.

Planas J (2017) State intervention in wine markets in the early $20^{\text {th }}$ century: Why was it so different in France and Spain. Revista de Historia Económica - Journal of Iberian and Latin America Economic History 35(29): 175-206.

Planas J, Medina-Albadalejo F (2017) Too little intervention or too much? The contribution of the State to the development of wine cooperatives in Spain. Revista de Historia Industrial 70: 77-107.

Pomés J (2000) La Unió de Rabassaires: Lluís Companys i el republicanisme, el cooperativisme i el sindicalisme pagès a la Catalunya dels anys vint. Abadia de Montserrat, Barcelona.

Pujol J (1984) Les crisis de malvenda del sector vitivinícola català entre el 1892 i el 1935. Recerques 15: 57-78

Raventós J (1922) L'art de fer bon vi. Escola Superior d'Agricultura, Barcelona. Rendé JM (1923) Organització i guiatge de sindicats agrícoles. Escola Superior d'Agricultura, Barcelona.

Riba J (1917) Cellers cooperatius de producció i venda. Riera, Barcelona.

Riera E (1908) Anuario-Riera, 1908. Barcelona.

Rinaudo Y (1980) Syndicalisme agricole de base: l'exemple du Var au début du XXe siècle. Le Mouvement Social 112: 79-98.

Robinson, J (ed) (2005) The Oxford companion to wine. Oxford University Press. Román C (2011) Las bodegas cooperativas en España: un sector en crecimiento, 
1950-2005. In Mateu AM (ed) Vinos y competitividad agroindustrial: un largo camino. Incihusa, Mendoza, 323-344.

Roudié Ph. (1983) Les caves coopératives en Gironde. In Le fait coopérative et mutualiste. Trames. Université de Limoges, pp. 618-623.

Santesmases J (1996) El cooperativisme agrari a Vila-rodona. Centre d'Estudis del Gaià, Vila-rodona.

Simpson J (2000) Cooperation and cooperatives in southern European wine production. New Frontiers in Agricultural History 1: 95-126.

Simpson J (2011) Creating wine: the emergence of the world industry. Princeton University Press, Princeton.

Soler-Becerro, R (2019) Viticultura, desigualtat i conflicte agrari. La lluita per la terra a la Catalunya vitícola. Publicacions Universitat Rovira i Virgili, Tarragona.

Tardy L (1929) La cooperation vinicole en France. Le Musée Social 11: 417-446.

Valentinov V (2007) Why are cooperatives important in agriculture? An organizational economics perspective. Journal of Institutional Economics 3(1): $55-69$.

Vilanova M, Moreno X (1992) Atlas de la evolución del analfabetismo en España, 1887-1981. Ministerio de Educación, Madrid. 
Table 1. The seven French departments with the most cooperative wineries, 1939

\begin{tabular}{|c|c|c|c|c|c|c|}
\hline & $\begin{array}{r}\text { I } \\
\text { Cooperative } \\
\text { wineries }\end{array}$ & $\begin{array}{r}\text { II } \\
\text { Cooperative wineries } \\
(\text { France }=100)\end{array}$ & $\begin{array}{r}\text { III } \\
\text { Hl of wine } \\
(\text { France }=100)\end{array}$ & $\begin{array}{r}\text { IV } \\
\text { Cooperatives' } \\
\text { market share }\end{array}$ & $\begin{array}{r}\mathrm{V} \\
\text { Average vine } \\
\text { holding (ha) }\end{array}$ & $\begin{array}{l}\text { VI } \\
\text { Vine holdings of } \\
\text { more than } 50 \text { ha }\end{array}$ \\
\hline Gard & 130 & 15.7 & 7.9 & 32.2 & 1.83 & 48 \\
\hline Aude & 112 & 13.6 & 9.9 & 20.9 & 3.09 & 177 \\
\hline Hérault & 109 & 13.2 & 21.4 & 14.3 & 2.73 & 189 \\
\hline Var & 98 & 11.9 & 4.4 & 52.6 & 1.84 & 26 \\
\hline Pyrénées-Orientales & 88 & 10.7 & 4.3 & 29.6 & 2.40 & 68 \\
\hline Vaucluse & 44 & 5.3 & 2.8 & 58.7 & 1.44 & 16 \\
\hline Bouches-du-Rhône & 44 & 5.3 & 2.6 & 35.5 & 1.42 & 36 \\
\hline France & 826 & 100.0 & 100.0 & 16.1 & 1.04 & 600 \\
\hline
\end{tabular}

Sources: I, II and IV: Confédération nationale des coopératives vinicoles (1955: 185); III, IV and V: Ministère du commerce (1939: 91); VI:

Institut national de la statistique et des études économiques (1959, II: 258). 
Table 2. Vineyard ownership in the departments of Hérault and Aude and in the cooperative winery 'L’Abri' (Lézignan, Aude), \%

\begin{tabular}{|c|c|c|c|c|c|c|c|c|}
\hline & \multicolumn{2}{|c|}{ Hérault (1929) } & \multicolumn{3}{|c|}{ Aude (1923) } & \multicolumn{3}{|c|}{ L'Abri (1934) } \\
\hline & $\begin{array}{r}\text { Vine- } \\
\text { growers }\end{array}$ & $\begin{array}{r}\text { Hectares of } \\
\text { vines }\end{array}$ & $\begin{array}{r}\text { Vine- } \\
\text { growers }\end{array}$ & $\begin{array}{r}\text { Hectares of } \\
\text { vines }\end{array}$ & $\begin{array}{r}\text { Hectolitres of } \\
\text { wine }\end{array}$ & Members & $\begin{array}{r}\text { Hectares of } \\
\text { vines }\end{array}$ & $\begin{array}{r}\text { Hectolitres } \\
\text { of wine }\end{array}$ \\
\hline$<1$ ha & 44.6 & 8.7 & 46.6 & 6.3 & 4.9 & 66.9 & 24.7 & 28.5 \\
\hline $1-5$ & 42.3 & 31.9 & 40.2 & 26.3 & 23.3 & 29.9 & 54.1 & 52.5 \\
\hline $5-30 \S$ & 11.2 & 32.0 & 11.7 & 39.2 & 40.3 & 3.2 & 21.2 & 19.0 \\
\hline $30-100 \S \S$ & 1.4 & 13.8 & 1.4 & 22.1 & 24.8 & - & - & - \\
\hline \multirow[t]{2}{*}{$>100 \S \S \S$} & 0.5 & 13.8 & 0.1 & 6.1 & 6.7 & - & - & - \\
\hline & 100.0 & 100.0 & 100.0 & 100.0 & 100.0 & 100.0 & 100.0 & 100.0 \\
\hline
\end{tabular}

$\S$ In Hérault, the holdings between 5 and 20 ha. $\S$ In Hérault, the holdings between 20 and 50 ha. $\S$ In Hérault, the holdings of more than 50 ha.

Note: In Hérault there were 63,391 vine-growers and 193,839 ha of vineyards. In Aude there were 37,978 vine-growers, 118,030 ha of vines and 6,508,926 hl of wine were produced. The cooperative winery 'L'Abri' had 499 members, who, together, owned 590 ha of vineyards and produced $31,745 \mathrm{hl}$ of wine.

Sources: For Hérault, Ministère de l'agriculture (1937: 28); for Aude, Pellegrin and Caillon (1939: 368); for 'L'Abri', Archives départementales de l'Aude, $75 \mathrm{~J} 177$. 
Table 3. Determinants of the setting-up of cooperative wineries. Negative binomial regressions (NBREG), zero-inflated negative binomial regressions (ZINB) and marginal effects at the mean (MEM). Dependent variable: cooperative wineries created by province until 1936

\begin{tabular}{|c|c|c|c|c|c|c|}
\hline & I & II & IIIa & IIIb & IVa & $\mathrm{IVb}$ \\
\hline & NBREG & NBREG & ZINB & MEM of IIIa & ZINB & MEM of IVa \\
\hline Bank of Spain & $0.02(1.31)$ & & & & & \\
\hline Vines $(\%)$ & $0.05(1.71) *$ & $0.13(2.64) * * *$ & $0.08(4.01) * * *$ & $0.18(3.36) * * *$ & $0.03(2.08) * *$ & $0.19(2.81) * * *$ \\
\hline Yields (hl/ha) & $0.02(0.79)$ & $0.002(0.08)$ & $-0.15(-3.03) * * *$ & $-0.13(-2.66) * * *$ & $-0.08(-3.71) * *$ & $-0.09(-2.63) * * *$ \\
\hline Vine holding in $1962\left(10^{3}\right)$ & $0.01(0.43)$ & & & & & \\
\hline Average vine holding in 1962 (ha) & $1.13(2.04) * *$ & & & & & \\
\hline Average vine holding in 1962 (ha) sq & $-0.08(-1.71) *$ & & & & & \\
\hline Illiteracy $(\%)$ & $-0.04(-1.45)$ & $-0.01(-0.58)$ & $0.007(0.40)$ & $0.006(0.40)$ & $0.007(0.40)$ & $0.005(0.38)$ \\
\hline Common water $(\%)$ & $0.15(3.00) * * *$ & $0.11(3.34) * * *$ & $0.08(-2.04) * *$ & $0.07(1.72) *$ & $0.06(2.65) * * *$ & $0.07(1.89) *$ \\
\hline Commons $(\%)$ & $0.02(0.63)$ & $0.03(1.45)$ & $0.10(6.05) * * *$ & $0.09(3.52) * * *$ & $0.05(6.03) * * *$ & $0.06(3.68) * * *$ \\
\hline Altitude $\left(10^{2} \mathrm{~m}\right)$ & $-0.34(-2.72) * * *$ & $-0.28(-3.37) * * *$ & $-0.41(-4.84) * * *$ & $-0.36(-3.40) * * *$ & $-0.23(-2.40) * *$ & $-0.26(-2.54) * *$ \\
\hline Sindicatos Agrícolas (SA) created up to 1927 & $-0.009(-2.25) * *$ & $-0.01(-2.80) * * *$ & $-0.009(-3.07) * * *$ & $-0.008(-2.99) * * *$ & $-0.008(-2.77) * * *$ & $-0.009(-2.34) * *$ \\
\hline SA created up to 1927 existing in 1933 & $0.02(1.48)$ & $0.02(2.94) * * *$ & $0.02(2.29) * *$ & $0.01(2.35) * *$ & $0.007(1.15)$ & $0.008(1.11)$ \\
\hline Catalonia (dummy) $\S$ & & & $3.34(5.57) * * *$ & $18.46(1.66) *$ & & \\
\hline \multicolumn{7}{|l|}{ Rabassa morta $\S \S$} \\
\hline 1. Girona & & & & & $1.42(4.62) * * *$ & $2.88(2.32) * *$ \\
\hline 2. Barcelona and Tarragona & & & & & $3.66(9.72) * * *$ & $34.91(2.28) * *$ \\
\hline Constant & $0.11(0.07)$ & $0.37(0.26)$ & $3.53(2.45) * *$ & & $2.35(1.94) *$ & \\
\hline $\mathrm{N} \S \S \S$ & 45 & 45 & 45 & 45 & 45 & 45 \\
\hline Mean dependent variable & 2.78 & 2.78 & 2.78 & & 2.78 & \\
\hline Vuong test & 0.067 & 0.128 & 0.015 & & 0.018 & \\
\hline Akaike test (AIC) & 135.90 & 136.73 & 124.23 & & 120.23 & \\
\hline Bayesian Information Criterion (BIC) & 161.19 & 154.80 & 147.72 & & 143.72 & \\
\hline
\end{tabular}

$\S 1$ = Lleida, Girona, Barcelona and Tarragona; $0=$ Spain without Catalonia. ${ }^{\S \S} 0=$ Spain without Girona, Barcelona and Tarragona. ${ }^{\S \S}$ Spain had 50 provinces, but information is lacking for five of them (Álava, Guipuzcoa, Vizcaya, Tenerife and Las Palmas). $*=p<0.1 * *=p<0.5 * * *=p<0.1$. Between parentheses, $z$-ratios. Robust standard errors. Inflating factor in IIIa and IVa: Vines. Sources: See Appendix 1. 
Table 4. Real and predicted number of cooperative wineries per province

(a) Model in Column IIIa in Table 3 and marginal effects at the mean

\begin{tabular}{lrrr}
\hline & Real number & $\begin{array}{r}\text { Predicted } \\
\text { number }\end{array}$ & $p$ \\
& & & \\
0. Spain without Catalonia & 1.0 & 0.7 & 0.001 \\
1. Catalonia & 21.3 & 19.1 & 0.087 \\
\hline
\end{tabular}

(b) Model in Column IVa in Table 3 and marginal effects at the mean

\begin{tabular}{lrrr}
\hline & Real number & $\begin{array}{r}\text { Predicted } \\
\text { number }\end{array}$ & $p$ \\
0. Spain without Girona, Barcelona and & & & \\
$\quad$ Tarragona & 1.1 & 0.9 & 0.000 \\
1. Girona & 3.0 & 3.8 & 0.005 \\
2. Barcelona and Tarragona & 38.0 & 35.8 & 0.020 \\
\hline
\end{tabular}

Source: Table 3 
Table 5. Determinants of the existence of cooperative wineries in municipal areas in the province of Tarragona, 1935. Probit models and average marginal effects (AME). Dependent variable: $1=$ one or two cooperative wineries; $0=$ no cooperative winery

\begin{tabular}{|c|c|c|c|c|c|}
\hline & $\begin{array}{c}\text { I } \\
\text { PROBIT }\end{array}$ & $\begin{array}{c}\text { IIa } \\
\text { PROBIT }\end{array}$ & $\begin{array}{c}\text { IIb } \\
\text { AME of IIa }\end{array}$ & $\begin{array}{c}\text { IIIa } \\
\text { PROBIT }\end{array}$ & $\begin{array}{c}\text { IIIb } \\
\text { AME of IIIa }\end{array}$ \\
\hline Vines $(\%)$ & $0.04(4.12) * * *$ & $0.04(4.03) * * *$ & $0.007(4.24) * * *$ & $0.04(2.82) * * *$ & $0.006(3.26) * * *$ \\
\hline Common water $(\%)$ & $0.05(2.96) * * *$ & $0.05(2.87) * * *$ & $0.01(3.33) * * *$ & $1.00(2.89) * * *$ & $0.01(2.92) * * *$ \\
\hline Commons $(\%)$ & $0.04(3.33) * * *$ & $0.04(3.13) * * *$ & $0.007(3.48) * * *$ & $0.09(3.29) * * *$ & $0.01(3.92) * * *$ \\
\hline Altitude $\left(10^{2} \mathrm{~m}\right)$ & $0.04(0.46)$ & $0.05(0.63)$ & $0.01(0.65)$ & $-0.17(-1.22)$ & $-0.03(-1.10)$ \\
\hline Gini Index (\%) & $0.02(1.12)$ & $0.02(1.09)$ & $0.003(1.04)$ & $0.01(0.63)$ & $0.002(0.63)$ \\
\hline Middle-sized owners (\%) & $-0.22(-1.14)$ & & & & \\
\hline Rabassaires (dummy) & $1.13(3.68) * * *$ & $1.12(3.60) * * *$ & $0.25(3.40) * * *$ & $1.93(2.45) * *$ & $0.32(2.66) * * *$ \\
\hline Vine-growers Federation of Catalonia (dummy) & $0.11(0.37)$ & $0.14(0.47)$ & $0.03(0.46)$ & $0.11(0.33)$ & $0.02(0.33)$ \\
\hline Agrarian Federation of Catalonia (dummy) & $-0.003(-0.01)$ & $-0.05(-0.14)$ & $-0.008(-0.14)$ & $0.06(0.11)$ & $0.01(0.11)$ \\
\hline $\mathrm{Km}$ to the train station & $0.05(2.32) * *$ & $0.05(2.46) * *$ & $0.009(2.33) * *$ & $0.09(3.31) * * *$ & $0.01(4.01) * * *$ \\
\hline Priorat (dummy) & & & & $2.93(3.75) * * *$ & $0.46(4.38) * * *$ \\
\hline Constant & $-4.62(-3.93) * * *$ & $-5.32(-4.99) * * *$ & & $1.84(0.69)$ & \\
\hline $\mathrm{N}$ & 180 & 180 & 180 & 114 & 114 \\
\hline Pseudo- $\mathrm{R}^{2}$ & 0.42 & 0.41 & & 0.55 & \\
\hline $\mathrm{Chi}^{2}$ & $127.10 * * *$ & $98.99 * * *$ & & $1410.33 * * *$ & \\
\hline Akaike test (AIC) & 145.51 & 145.45 & & 100.86 & \\
\hline Bayesian Information Criterion (BIC) & 193.41 & 190.15 & & 152.85 & \\
\hline
\end{tabular}

$*=p<0.1 * *=p<0.5 * * *=p<0.01$. Between parentheses, z-ratios. Clustered standard errors. Sources: See Appendix 2. 
Table 6. Determinants of the existence of cooperative wineries in municipal areas in the province of Tarragona. Ordered probit models (OPROBIT) and average marginal effects (AME). Dependent variable: $1=$ no cooperative; $2=$ one cooperative; $3=$ two cooperatives.

\begin{tabular}{|c|c|c|c|}
\hline & $\begin{array}{c}\text { I } \\
\text { OPROBIT }\end{array}$ & $\begin{array}{c}\text { IIa } \\
\text { OPROBIT }\end{array}$ & $\begin{array}{c}\text { IIb } \\
\text { AME of Column IIa } \\
(\text { Outcome } 3)\end{array}$ \\
\hline Bank of Spain (dummy) & $0.53(2.17) * *$ & $0.61(2.60) * * *$ & $0.07(2.13) * *$ \\
\hline Vines $(\%)$ & $0.04(4.88) * * *$ & $0.05(4.64) * * *$ & $0.004(4.57) * * *$ \\
\hline Illiteracy $(\%)$ & $-0.01(-0.74)$ & $-0.02(-1.62)$ & $-0.002(-1.61)$ \\
\hline Common water (\%) & $0.04(3.44) * * *$ & $0.03(1.91) *$ & $0.003(2.06) * *$ \\
\hline Commons $(\%)$ & $0.03(3.20) * *$ & $0.03(2.79) * * *$ & $0.003(3.24) * * *$ \\
\hline Altitude $\left(10^{2} \mathrm{~m}\right)$ & $0.09(1.32)$ & $0.15(1.87) *$ & $0.02(1.81) *$ \\
\hline Land owners $\left(10^{2}\right)$ & $0.39(5.13) * * *$ & & \\
\hline Land owners $\left(10^{2}\right) \mathrm{sq}$ & $-0.02(-3.38) * *$ & & \\
\hline Inhabitants $\left(10^{3}\right)$ & & $0.92(5.65) * * *$ & $0.09(4.27) * * *$ \\
\hline Inhabitants $\left(10^{3}\right) \mathrm{sq}$ & & $-0.06(-4.42) * * *$ & $-0.005(-3.54) * * *$ \\
\hline Gini Index $(\%)$ & $0.02(1.07)$ & $0.01(0.65)$ & $0.001(0.64)$ \\
\hline Rabassaires (dummy) & $0.86(3.01) * * *$ & $0.84(2.82) * * *$ & $0.10(2.57) * *$ \\
\hline Vine-growers Federation of Catalonia (dummy) & $0.08(0.30)$ & $-0.08(-0.27)$ & $-0.008(-0.28)$ \\
\hline Agrarian Federation of Catalonia (dummy) & $0.09(0.36)$ & $-0.003(-0.01)$ & $-0.0003(-0.01)$ \\
\hline $\mathrm{Km}$ to the train station & $0.02(1.25)$ & $0.03(1.50)$ & $0.003(1.47)$ \\
\hline $\mathrm{N}$ & 180 & 180 & 180 \\
\hline Pseudo- $\mathrm{R}^{2}$ & 0.31 & 0.36 & \\
\hline $\mathrm{Chi}^{2}$ & $214.32 * * *$ & $140.49 * * *$ & \\
\hline Akaike test (AIC) & 206.35 & 193.79 & \\
\hline Bayesian Information Criterion (BIC) & 254.24 & 241.68 & \\
\hline
\end{tabular}
$*=p<0.1 * *=p<0.5 * * *=p<0.01$. Between parentheses, $\mathrm{z}$-ratios. Clustered standard errors. Source: Appendix 2 
Table 7. Determinants of the construction of modernist style cooperative wineries in municipalities in the province of Tarragona. Probit models and average marginal effects (AME). Dependent variable: 1 if the municipality has a modernist winery, 0 otherwise

\begin{tabular}{|c|c|c|c|c|}
\hline & I & II & IIIa & $\mathrm{IVb}$ \\
\hline & PROBIT & PROBIT & PROBIT & AME of Column IIIa \\
\hline Bank of Spain (dummy) & $0.88(2.38) * *$ & $1.08(2.28) * *$ & $1.10(2.37) * *$ & $0.11(2.87) * * *$ \\
\hline Vines $(\%)$ & $0.03(2.07) * *$ & $0.04(2.22) * *$ & $0.03(1.87) *$ & $0.003(2.11) * *$ \\
\hline Illiteracy $(\%)$ & $0.03(1.58)$ & $0.02(0.94)$ & $0.02(1.01)$ & $0.002(0.97)$ \\
\hline Common water (\%) & $-0.16(-2.54) * *$ & $-0.18(-1.69) *$ & $-0.25(-2.19) * *$ & $-0.02(-2.34) * *$ \\
\hline Commons $(\%)$ & $-0.02(-0.89)$ & $-0.04(-1.29)$ & $-0.04(-1.43)$ & $-0.004(-1.70) *$ \\
\hline Altitude $\left(10^{2} \mathrm{~m}\right)$ & $0.10(0.97)$ & $0.19(1.52)$ & $0.07(0.56)$ & $0.006(0.61)$ \\
\hline Land owners $\left(10^{2}\right)$ & $0.31(2.06) * *$ & & & \\
\hline Land owners $\left(10^{2}\right) \mathrm{sq}$ & $-0.01(-1.66) *$ & & & \\
\hline Inhabitants $\left(10^{3}\right)$ & & $1.60(3.29) * * *$ & $1.23(2.47) * *$ & $0.11(1.95) *$ \\
\hline Inhabitants $\left(10^{3}\right) \mathrm{sq}$ & & $-0.19(-2.17) * *$ & $-0.12(-1.26)$ & $-0.01(-1.07)$ \\
\hline Gini Index (\%) & $0.03(2.23) * *$ & $0.03(2.38) *$ & $0.03(2.87) * * *$ & $0.003(3.20) * * *$ \\
\hline Vine-growers Federation of Catalonia (dummy) & $0.30(0.71)$ & $0.15(0.12)$ & $0.03(0.71)$ & $0.005(0.12)$ \\
\hline Agrarian Federation of Catalonia (dummy) & $0.15(0.44)$ & $-0.13(-0.36)$ & $-0.27(-0.79)$ & $-0.23(-0.83)$ \\
\hline Rabassaires (dummy) & $1.26(3.06) * * *$ & $1.35(3.05) * * *$ & $1.45(3.26) * * *$ & $0.17(3.13) * * *$ \\
\hline $\mathrm{Km}$ to the train station & $0.05(2.67) * * *$ & $0.06(2.64) * * *$ & $0.75(3.08) * * *$ & $0.007(3.32) * * *$ \\
\hline Two cooperative wineries (dummy) & & & $1.14(2.67) * * *$ & $0.10(2.37) * *$ \\
\hline Constant & $-7.94(-4.01) * * *$ & $-9.10(-3.69) * * *$ & $-8.55(-.50) * * *$ & \\
\hline $\mathrm{N}$ & 180 & 180 & 180 & \\
\hline Pseudo- $\mathrm{R}^{2}$ & 0.40 & 0.46 & 0.50 & \\
\hline $\mathrm{Chi}^{2}$ & $247.42 * *$ & $111.81 * * *$ & $334.41 * * *$ & \\
\hline Akaike test (AIC) & 96.04 & 88.70 & 85.80 & \\
\hline Bayesian Information Criterion (BIC) & 140.74 & 133.40 & 133.40 & \\
\hline
\end{tabular}

$*=p<0.1 * *=p<0.5 * * *=p<0.01$. Between parentheses, $\mathrm{z}$-ratios. Clustered standard errors.

Sources: Appendix 2. 


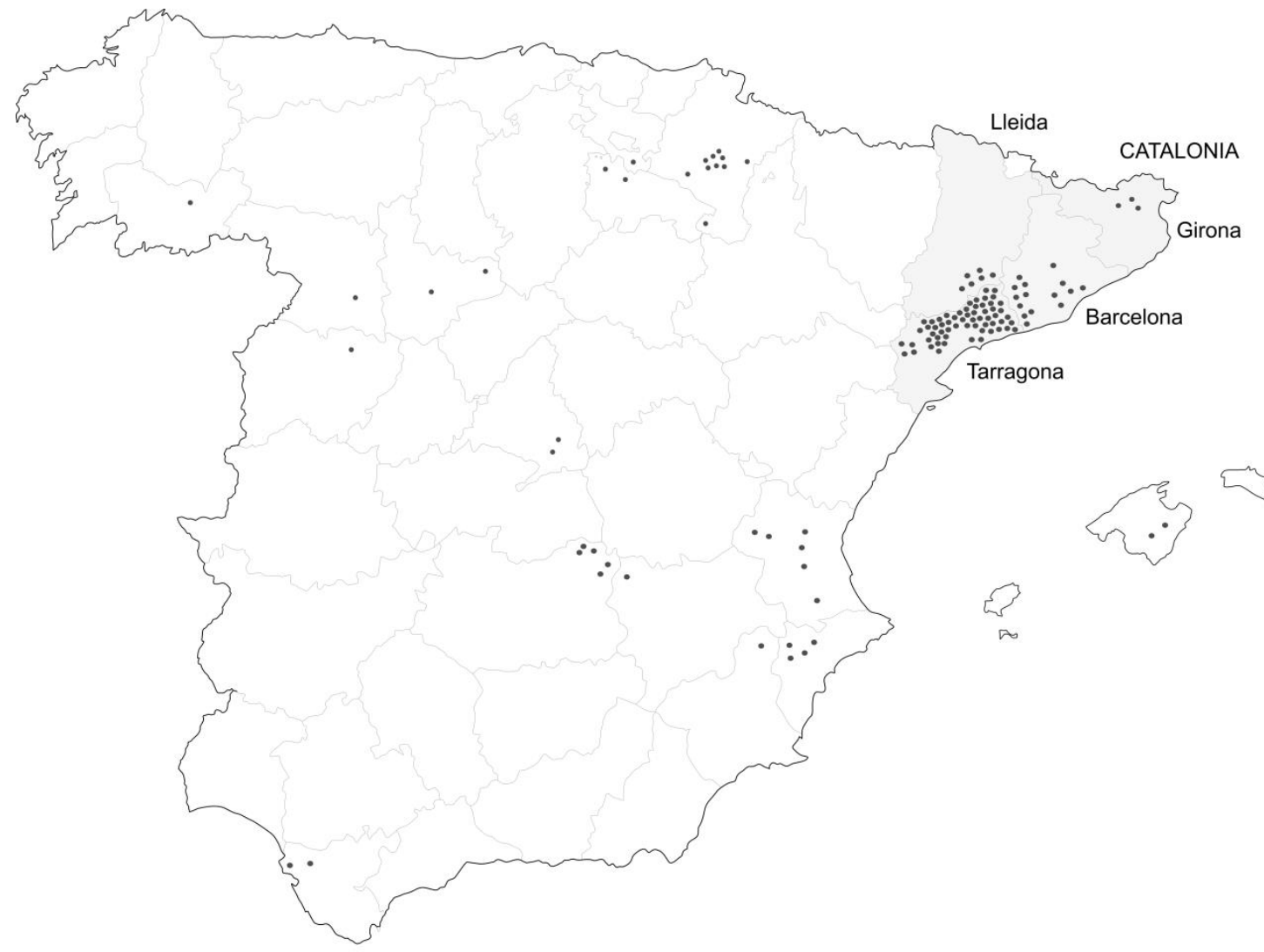

Fig 1 Cooperative wineries built in Spain, by provinces, up to 1936

Sources: Appendix 1. 